\title{
Exploring the Teaching of Reading Skills in Nigerian Secondary Schools
}

\author{
Abu-Ubaida S. ${ }^{1}$, Amina U.U. ${ }^{2}$, Aishatu A.B. ${ }^{3}$ and Abubakar U.U. ${ }^{3}$ \\ Department of Educational Foundations Usmanu Danfodiyo University, Sokoto ${ }^{I}$ \\ Aminu Saleh College of Education, Azare Bauchi State Nigeria ${ }^{2}$ and 3
}

\begin{abstract}
It is believed that of all the core competencies recognized to contribute to lifelong learning and sustainable development, none is quite as central as the ability to read and write. The paper has as gist, exploring reading skills with regard to its teaching in secondary schools as well as factors surrounding it (both for and against). The paper delved into the conceptual meaning of reading skills and make epitomical overview on the categories of reading skills thus, skimming, scanning, intensive reading and extensive reading as majors among others. The paper also examined other phenomena salient to the topic of discussion. They include, reading difficulties, causes and taxonomies of reading difficulties, remediation of reading difficulties and approach to teaching reading skills. In conclusion, the paper divulges insinuated ways to promoting efficiency in teaching reading skills in secondary schools. One of such ways the need joint intervention of parents and teacher into the reading difficulties of children, another is introduction and incorporation of teaching reading as a course in teacher-training program.
\end{abstract}

\section{Introduction}

Being able to read fluently depends on a number of different skills. Moreover, it is the teachers' role and responsibility to provide, plan and teach an effective reading program that will enable the learner to become a skilful reader (Chinttha, 2008). Being focus and selective in one's reading habits will reduce the time one spends reading. Therefore, it is more important to improve one's reading skills than improving reading speed (Allan \& Edward, 1980). Trudell, Dowd, Piper, \& Bloch, (2012) hold that, of all the core competencies recognized to contribute to lifelong learning and sustainable development, none is quite as central as the ability to read and write (Medadi, 2014). However, the ability to read is one determiner of students' success or failure. Therefore, they must form the habit of reading to perform well in all subjects. This is because good reader has a better opportunity for greater achievement (Adeniji \& Omale, 2010). To this effect, Amutheazi (2000) consider it necessary, as an urgent matter, to investigate into the causes of poor reading comprehension among our pupils with a view to finding a lasting solution to the problem.

Reading instruction needs to be based on training students in new ways of talking and thinking about text. Psychologist have shown that students learn new strategies of thinking process most effectively when they are consciously aware of what they are doing (Brown, Armbruster \& Baker, 1986). However, once students are conscious of the processes, they can monitor their comprehension and apply appropriate strategies as needed for comprehending a text (Brown in Beatrice, 2008). Reading skills is important as researchers discovered a mutual relationship between students' academic reading skills and academic success, in the past decades (Julian, 2009).

The Concept of Reading and Reading Skills

Reading is the term used to refer to a deliberate looking at, and understanding written language (Willians in Kalindi, 2005). Reading is the process shaped partly by the text, partly by the reader's background and partly by the situation the reader occurs in (Hunt, 2004). On the other hand, reading skills are the cognitive process that a reader uses in making sense of a text (Beatrice, 2008). Reading skills is therefore concerned with all the processes involved in an attempt to ease reading as well as comprehend the content. A large portion of write up could be understood within the shortest possible time, if appropriate reading skills were employed (Allan \& Edward, 1980). Royal, (2015) holds that reading skills may include letter and sight word recognition, knowing letter sounds, and combinations of letter sounds, as well as what happens when all those sounds blend together.

\section{Rationale for Teaching Reading Skills}

The National Capital Language Resource Center (NCLR), (2004) outlines some goals of teaching reading skills, thus:

i. They develop students' awareness of the reading process and reading strategies by asking students to think and talk about how they read in their native language.

ii. They allow students to practice the full repertoire of reading strategies by using authentic reading tasks. They encourage students to read to learn (and have an authentic purpose for reading) by giving students some choice of reading material. 
iii. When working with reading tasks in class, they show students the strategies that will work best for the reading purpose and the type of text. They explain how and why students should use the strategies.

iv. They have students practice reading strategies in class and ask them to practice outside of class in their reading assignments. They encourage students to be conscious of what they're doing while they complete reading assignments.

v. They encourage students to evaluate their comprehension and self-report their use of strategies. They build comprehension checks into in-class and out-of-class reading assignments, and periodically review how and when to use particular strategies.

vi. They encourage the development of reading skills and the use of reading strategies by using the target language to convey instructions and course-related information in written form: office hours, homework assignments, test content.

vii. They do not assume that students will transfer strategy use from one task to another. They explicitly mention how a particular strategy can be used in a different type of reading task or with another skill (NCLR, 2004).

\section{Types of Reading Skills}

Categorizations of reading skills depends on factors considered in the context of reading. However, there are different ways of categorizing reading skills (Maija, 2012). Nonetheless, several scholars and writers have given different categories of reading skills (see, Carl, 1976; Allan \& Edward, 1980; Beatrice, 2008; Maija, 2012; Marcia, 2013; John, 2013; Army \& Terry, 2016). Types of reading skills could be discussed as follows:

$i$. Skimming: This is sometimes refers to as gist reading. It is the process of reading quickly by skipping some portions of the write-up, thus concentrating only on main points.

ii. Scanning: This is getting one's eyes quickly scuttling across sentences or paragraphs looking for a piece a pieces or of information.

iii. Intensive Reading: Reading here is done with the intention of mastering and retention of information for a long period. Knowledge resulted from this type of reading persists in one's long-term memory.

iv. Extensive Reading: This is mostly reading for pleasure (Carl, 2012). It is reading of high amount of interested materials, usually out of class (Allan \& Edward, 1980; Long and Richard, 1987; Karl, 2012).

\section{Stages in Reading Development}

Kemba, (2005) outlines the stages of reading development as follows:

i. The pre-reading stage

ii. Beginning reading stage

iii. Developing reading fluency stage

iv. Increasing reading ability and developing of reading interest of students

v. Enhancing and refining reading skills (Kemba, 2005).

\section{Challenges Faced by Teachers in Teaching Reading Skills in Secondary Schools}

In virtually every class, there could be a learner with learning difficulty. Sometimes, teachers even come across students who (the students) believed they cannot read. Moreover, teachers have been working under difficult circumstances, as too many students in a class and poor students' attendance among others, are issues in Nigerian secondary schools since time immemorial. Furthermore, the shortage of teaching and learning materials is a challenge to teaching reading skills in secondary schools.(Kalindi, 2005; Linda, 2013). Categorically therefore, the challenges faced by teachers teaching reading skills in Nigerian secondary schools include the following:

i. Poor background and preliminary knowledge in English language studies, thus pre-primary and primary orientation on English language,

ii. Lack of motivation among students in the study of English language in general and specifically reading skills,

iii. Over populated classes,

iv. Poor student's attendance and skipping lectures,

v. Lack of adult readers as model,

vi. Poor libraries,

vii. Shortage of teaching and learning materials and Inadequate/absence of language laboratories among others (Oyetunde, 1986; Unoh, 1986; Kemba, 2005; Folaranmi, 2007; Adeniji \& Omale, 2010; Masello, 2014).

However, it is to be noted that students are also, to great extent, responsible for the continual difficulties in reading. Although the question of whether today's students are reading seems to depend on whom you ask, Vicki \& Dana, (2012) quoted Gioia that:

i. $\quad$ Reading is declining as an activity among teenagers.

ii. College attendance no longer guarantees active reading habits.

iii. Even when reading does occur, it competes with other media. 
iv. American families are spending less money on books than at almost any other time during the past two decades.

v. Among high school seniors, the average reading proficiency score has declined for virtually all levels of reading.

vi. Reading proficiency rates are stagnant or declining among all adults (Giogia in Vicki \& Dana, 2012: xi).

\section{Causes of Reading Difficulties}

Reading failure is mostly caused by failure to acquire phonological awareness and skills in alphabetic coding (Mando, 2008). There have been debates on either reading difficulties are products of neurological or environmental factors (Maruyama, 2007). Maruyama (2007) considers three factors justifying causes of reading difficulties to be neurological. They are:

(i) Disorientation and disorganization in recognition of visual patterns due to brain damage,

(ii) Hereditary relationship of reading ability and

(iii) Interrelationship between visual, auditory, temporal and kinesthetic disorientation and disorganization.

However, Ojanen (2007) believes reading difficulty can be a product of inadequate teaching (Linda, 2013). The home environment also plays a vital role on students reading ability (Paananen in Linda, 2013). It is also observed that however, girls are better than boys when it comes to reading (UNESCO in Linda, 2013). There is some evidence that one of the stumbling blocks to reading progress is the irregularity of the sound/symbol relationships of the English language. For instance, the long vowel sound /i:/ might be represented with /ee/ and/or /ey/ among others, as in peel /fi:l/ and key /ki:/ (Moyle \& Donald, 1974).

\section{Taxonomy of Reading Difficulties}

During reading, students encounter difficulty in different stages. Adeniji \& Omale (2010) said that Lawal did diagnostic testing of reading achievement of selected secondary schools in Samaru, Zaria in the year 1982. He described the students' reading problems as: omission, substitution, reversal, mispronunciation, sight, vocabulary, not up to grade level, nervousness, slow reading, and lack of comprehension.

i- Failure to understand words: This is where a student finds it difficult to know the meaning of a certain word or words in a piece of writing. Thereof, the entire write-up may appear meaningless to such a student.

ii- Failure to understand sentence: Here, is the situation in which a student fails to comprehend an important sentence or sentences in a piece of writing. Hence, the entire meaning of the write-up would appear contradictory to such a student.

iii- Failure to understand how sentences relate to one another: If a student does not identify with the coherence among sentences, the piece of writing as a whole would be of no meaning to him.

iv- Failure to understand how the whole text fits together: There are instances where a student might be free from all the above stages of reading difficulties, yet finds it difficult to comprehend the write-up as a whole.

However, Harrison (1998) affirms that, proficient reader must to possess:

i. Automatic, rapid letter recognition ,

ii. Automatic, rapid word recognition,

iii. The ability to use context as an aid to comprehension and

iv. The ability to use context when necessary as a conscious aid to word recognition.

\section{Remediation of Reading Difficulties}

It is advisable to know the causes of learning difficulties so as to decide best how to intervene (Mando, 2008). It is important to put necessary measures in place as soon as parents or teachers notice child with reading difficulty. Many scholars are of the view that, the school, the students, the teachers and the parents must all put in efforts in order to improve the reading skills of the students (Bond \& Tinker 1973; Oyerokun, 1993; Chihemen, 2007). One method of tackling such problems might be using Professor Heikki's computer based learning game called 'Ekapeli' (Kachanga in Linda, 2013).

\section{Revisiting the Five Basic Premises of Teaching Reading}

Vicki, \& Dana, (2012) Discuss the brain-based research with regard to the five premises that cognitive science previously identified as basic to teaching content-area reading skills. Thus, according to them, they still hold true and valid. They are:

i. Constructing the Meaning of a Text: A reader actively constructs meaning of a text by making seemingly logical and deliberate connections between an existing knowledge and new information about a topic (Vacca \& Vacca, 1993; Duke \& Pearson, 2002).

ii. The Role of Prior Knowledge in Learning: The most important variable in learning with texts is a reader's prior knowledge. By activating prior knowledge and generating the learner's interest, a teacher creates a context for students to approach reading with purpose and anticipation (Vacca \& Vacca, 1993, 2005; Vicki, U. \& Dana, F. 2012).

iii. The Reader's Comprehension is Dependent on Metacognition: Metacognition is the ability to think about and control the thinking process before, during, and after reading. Students who have learned 
metacognitive skills can plan and monitor their comprehension, adapting and modifying their reading accordingly (Vicki, U. \& Dana, F. 2012).

iv. Reading and Writing are Integrally Related: Many researchers have agreed that reading and writing are naturally connected, even thoug there have been a debate on the specific connections among them. However, each involves generating ideas, logically organizing them, revisiting them several times until they make sense, and then revising or rethinking them as needed (Laflamme, 1997; Vicki, U. \& Dana, F. 2012).

v. Learning Increases with the Collaboration of Students: This is however, the believe that students learn by interacting with others in the classroom, by generating and asking questions, and by discussing their ideas freely with the teacher or one another. Conversation provides an opportunity for the speaker to deepen his or her understanding of an idea or topic (Vicki, U. \& Dana, F. 2012).

\section{Approach to Teaching Reading Skills}

i- Focus on one skill at a time.

ii- Explain the purpose of working on the skill, and convince the students of its importance in reading effectively. Work on and example of using the skill with the whole class. Explain your thinking aloud as you do the exercise.

iii- Assign students to work in pairs on an exercise where they practice using the same skill. Require them to explain their thinking to each other as they work.

iv- Discuss students' answers with the whole class. Ask them to explain how they got their answers. Encourage polite disagreement and require explanations of any differences in their answers.

v- In the same class, and in the next few classes, assign individuals to work on more exercises that focus on the same skill with increasing complexity.

vi- Ask students individually to complete the exercise using the skill to check their own ability and confidence in using it.

vii- In future lesson, lead the students to apply the skill as well as previously mastered skills, to variety of texts (Beatrice, 2008).

However, Block \& Parris, (2008), according to Vicki, U. \& Dana, F. (2012), maintains that, the following is a list of nine strategies that have been helpful in teaching reading skills:

i. Predict by examining the features, or reader aids, present throughout the text,

ii. Monitor through the use of metacomprehension,

iii. Question when meaning is unclear,

iv. Construct images and mental pictures while reading,

v. Use look-backs, rereads, and fix-it strategies,

vi. Infer quickly, connecting ideas to known information and previous experiences,

vii. Find main ideas, summarize, and draw conclusions,

viii. Evaluate by noting aspects of story grammar and structure and

ix. Synthesize all noticeable aspects of a text, from reader aids to conclusions (Block \& Parris, 2008; Vicky, 2012).

\section{Conclusion}

Although there have been debates on either reading difficulties are products of neurological or environmental factors, it is believed that reading failure is mostly caused by failure to acquire phonological awareness and skills in alphabetic coding. However, being able to read fluently depends on a number of different skills. Therefore, it is the teachers' role and responsibility to provide, plan and teach an effective reading program that will enable the learner to become a skilful reader. A good teacher is capable of unleashing the natural reading wisdom of students, and indeed minimizing the reading difficulties of students with disabilities.

Nevertheless, reading difficulties of students is of various stages, thus; failure to understand words, failure to understand sentences, failure to understand how sentences relate to one another as well as failure to understand how the whole text fit together. More so, certain factors are responsible for the encumbering of teaching reading skills in Nigerian secondary schools. They include, lack of motivation and poor background of students, over populated classes and inadequate teaching and learning materials among others. However, with the appropriate reading materials, a conducive environment and teachers with adequate educational qualifications and pedagogy of teaching, good reading skills would be impacted to the students. Reading is indeed indispensable in secondary schools and thus government, teachers and parents have major roles to play in ensuring that students acquire good reading skills.

\section{Suggestions}

i- Parents and teachers should jointly intervene into reading difficulties of child with immediate effect.

(a) Parents should provide a stimulating reading environment for their children. They should provide books for them and encourage them to read at home. Books should be provided for them to improve their reading. 
(b) Teachers, on the other hand, must acknowledge the importance of reading skills and shall plan an effective program of reading with a focus on promoting reading culture and skills among students in their schools.

ii- Teachers should be provided with adequate teaching and learning materials. More so, the welfare of teachers should be held at appropriate extent. Government at the federal, state, and local levels has the responsibility of providing appropriate materials for teaching reading skills. Also, it is the government's task to provide libraries for our secondary schools. Definitely, since the absence of libraries is a factor responsible for the deficiency in reading skills.

iii- Teaching reading skills should be introduced and incorporated as a course in the teacher-training program.

\section{References}

[1]. Adeniji, M. A. Omale, A. (2010).Teaching Reading Comprehension in Selected Primary Schools in Oyo State, Nigeria.Library Philosophy and Practice (e-journal). Paper 349, ISSN 1522-0222

[2]. Allan, A. \& Edward, E. S. (1980).Teaching the Process of Reading Comprehension.In Technical Report No. 182.Illinois: Bolt Beranek and Newman Inc.

[3]. Amutheazi, E. (2000). Education and the challenge of patriotism in Nigeria: A goodwill message. In Babarinde, K. (ed.). Education and the Challenge of Patriotism in Nigeria. A publication of Philosophy of Education Association of Nigeria.

[4]. Beatrice, S.M. (2008). Teaching Reading in Second Language. Retrieved from, www.longmanhomeusa.com

[5]. Block, C. C. \& Parris, S. R. (Eds.) (2008). Comprehension instruction: Research-based best practices. solving problems in the teaching of literacy (2nd Ed.). New York: Guilford Press.

[6]. Bond, G.L. \& Tinker, M. (1973). Reading difficulties: Their diagnosis and correction. Englewood Cliffs NJ: Prentice-Hall.

[7]. Brown, A. L., Ambruster, B.B. \& Baker, L. (1986). The role of Metacognition in Reading and Studying. In Osanu, J. (ed) Reading Comprehension: From Research to Practice. Hillsdale: Lawrence Erlbaum Association.

[8]. Chiahemen, F. (2007). Retraining of primary school teachers will boost UBE. Daily Independent Newspaper, May 17, A3.

[9]. Chintha, M. (2008). Teaching Reading in the Early Grades: A Teacher's HandBook. South Africa: Plaatje House.

[10]. Dole, J. A., Valencia, S. W., Greer, E. A. \& Wardrop, J. L. (1991). Effects of two types of prereading instruction on the comprehension of narrative and expository text. In Reading Research Quarterly, 26(2), 142-159.

[11]. Duke, N. \& Pearson, D. (2002). Effective practices for developing reading comprehension. In Farstrup, A. E. \& Samuels, S. J. (Eds.) What Research Has to Say About Reading Instruction (3rd ed.). Newark, DE: International Reading Association.

[12]. Ezekiel A. Abe (1991).Teaching reading in Nigerian primary schools.In Teaching Horizon Vol. 31. Berkeley Electronic Press.

[13]. Folaranmi, Y.(2007). Challenges of making the teaching profession viable. The Nigerian Education Times 14-May-June: 37.

[14]. Harrison, C. (1998).Methods of Teaching Reading: Key Issues in Research and Implications for Practice. Nottingham: SOEID.

[15]. Hunt, R.A. (2004). Reading and Writing for Real: Why it Matters for Learning. Atlantic Universities' Teaching Showcase. Retrieved from, www.mansfield.edu

[16]. John, T. (2013). This Much I Know About How to Teach Reading Skills to our Weakest Readers. Retrieved from, https://johntomsett.com

[17]. Julian, H. (2009). The Importance of Teaching Academic Reading Skills in First-Year University Courses. In The International Journal of Research and Review. Retrieved from, www.mansfield.edu

[18]. Kaalindi, S.C. (2005). The Inpact of the New Primaty Reading Program on the Poor Readers. M. Ed. Dissertation. Lusaka: University of Zambia.

[19]. Karl, M. (2012). Different Reading Techniques and When to Use Them. Retrieved from, www.howtolearn.com

[20]. Kemba, A. N. (2005). Guide to Teaching Reading at the Primary School Level. France: 7, place de Fontenoy, 75352 PARIS 07 SP

[21]. Laflamme, J. G. (1997). The effect of the Multiple Exposure Vocabulary Method and the Target Reading/Writing Strategy on test scores. Journal of Adolescent and Adult Literacy, 40(5), 372-381.

[22]. Langer, J. A. (2000). Guidelines for teaching middle and high school students to read and write well: Six features of effective instruction. New York: National Research Center on English Learning and Achievement.

[23]. Linda, M. 92013). Reading Difficulties in Grade Six Learners and Challenges Faced By Teachers In Teraching Reading: A Case Study of Chadiza and Chipata Dristrics, Zambia. A Dissertation Submitted to the University of Zambiya in Partial Fulfilment of the requirements of the degree of Master of Arts in Child and Adolescent Psychology.

[24]. Long, M. \& Richards, J. (1987). Methodology in TESOL. Boston: Heinle \& Heinle Publishers.

[25]. Maija, M. (n.d.). Types of Reading. Retrieved from, http://fis.ucalgary.ca

[26]. Mando, R. (2008). The Effect of Teaching Basic Literacy Skills by Using Computer-assisted Learning. M.A. Dissertation. Helski: University of Jyvaskyla.

[27]. Maruyama, M. (2007). Reading Disability: A Neurological Point of View. Retrieved from, http://dspace.unza.zm

[28]. Masello , P. (2014). Possibilities and Challenges of Teaching Reading in a Multi-Grade Classroom. In Mediterranean Journal of Social Sciences, Vol. 5. Rome-Italy: MCSER Publishing

[29]. Medadi, E. S. (214). The Challenges of Teaching Reading in Uganda: Curriculum guidelines and language policy viewed from the classroom. In Apples - Journal of Applied Language Studies Vol. 8.Uganda: Centre for Applied Language Studies.

[30]. Moyle, L, \& Donald, M. (1974). Modern innovations in the teaching of reading. London: University of London Press.

[31]. National Capital Language Resource Center (NCLR) (2004).Teaching reading.Retrieved from: http://www.nclrc. org/essentials/ reading/goalsread.htm

[32]. Oyerokun, S. O. (1993). Listening comprehension skills. Ibadan: Adebanke Commercial Press.

[33]. Oyetunde, I. (1986). Teaching reading comprehension and summary writing in the secondary schools. Jos: Museum Press.

[34]. Royal, K. (2015). The challenges of teaching reading skills. Retrieved from: www.connectedlearning.com

[35]. Trudell, B., Dowd, A. J., Piper, B. \& Bloch, C 2012. Early grade literacy in African classrooms: Lessons learned and future directions. A working document to serve as a basis for discussions at the Triennale Meeting of Association for the Development of Education in Africa (ADEA). Retrieved from www.africanstorybookproject.pwias.ubc.ca

[36]. Unoh, S. (1986). The study of reading. Ibadan: University Press.

[37]. Vacca, R. T. \& Vacca, J. L. (1993). Content area reading (4th ed.).New York: Harper Collins.

[38]. Vacca, R. T. \& Vacca, J. L. (2005). Content area reading: Literacy and learning across the curriculum (8th ed.) Boston: Allyn \& Bacon.

[39]. Vicki, U. \& Dana, F. (2012). Teaching reading in the cintent areas. USA: ASCD Publications. 